\title{
PENINGKATAN KAPASITAS KEMAMPUAN PERAWAT DALAM MENENTUKAN DIAGNOSA KEPERAWATAN BERDASARKAN TEORI PATIENT CENTERED DI RSUD BANGIL
}

\author{
Nurser Capacity Improvement In Determining Nursing Diagnosis Based On Patient \\ Centered Theory In Bangil Hospital
}

\author{
Moch Bahrudin $^{(1)}$, Tanty Wulan Dari ${ }^{(2)}$ Krisnawati $^{(3)}$ \\ Prodi D III Keperawatan Sidoarjo-Poltekkes Kemenkes Surabaya \\ HP : 081330356330 , Email : bahrudin_moch@yahoo.com
}

\begin{abstract}
ABSTRAK
Salah satu dari proses keperawatan adalah menentukan diagnosa keperawatan. Penentukan diagnosa keperawatan berdasarkan teori yang digunakan salah satunya adalah teori dari Carpenito yaitu berdasarkan respon pasien sebagai pedoman dalam penentuan diagnosa keperawatan. Teori tersebut sudah tidak sejalan dengan keadaan yang berkembang saat ini. Maka teori ini tidak bisa menjawab kebutuhan pasien karena pasien yang dirawat di rumah sakit tidak selalu bisa merespon atau mengeluh. Berdasarkan masalah tersebut maka penulis memberikan petunjuk penentuan diagnose keperawatan berdasarkan teori abdella faya yaitu berdasarkan gangguan fisiologis tubuh..

Sasaran pengabdian adalah perawat di ruang perawatan RSUD Bangil. Permasalahan diselesaikan dalam dua tahapan kegiatan yaitu persiapan dan pelaksanaan. Persiapan dilakukan dengan melakukan penelitian pada tahun 2017 untuk melihat kondisi di lapangan mengenai tata cara perawat dalam menentukan diagnose keperawatan. Pelaksanaan dilakukan dengan metode ceramah yaitu Teknik penentuan diagnose keperawatan dan Latihan kasus sebagai bentuk kegiatan workshop penentuan diagnose keperawatan.

Hasil kegiatan pelatihan menunjukkan tingkat keberhasilan dengan indikasi adanya kesesuaian materi dengan kebutuhan perawat dalam menentukan diagnose keperawatn, adanya respon yng positif dari peserta dan Sebagian besar $(90 \% 0$ peserta telah memahami konsep dan cara menentukan diagnose keperawatan.
\end{abstract}

Kata kunci : penentuan, diagnosa keperawatan, Patient Centered, RSUD Bangil

ABSTRACT
One of the nursing processes is determining nursing diagnoses. The determination of nursing diagnoses is based on the theory used, one of which is Carpenito's theory, which is based on patient responses as a guide in determining nursing diagnoses. This theory is not in line with the current situation. So this theory cannot answer the needs of patients because patients who are hospitalized cannot always respond or complain. Based on these problems, the authors provide instructions for determining nursing diagnoses based on the Abdella Faya theory, which is based on body physiological disorders.

The service targets are nurses in the Bangil Hospital treatment room. The problem is resolved in two stages of activity, namely preparation and implementation. Preparation is carried out by conducting research in 2017 to see conditions in the field regarding nurses' procedures for determining nursing diagnoses. Implementation is carried out by the lecture method, namely the technique of determining nursing diagnoses and case exercises as a form of nursing diagnosis determination workshop activities.

The results of the training activities show the level of success with an indication of the suitability of the material with the needs of nurses in determining nursing diagnoses, a positive response from the participants and the majority (90\% of participants have understood the concept and how to determine nursing diagnoses.

Key words: determination, nursing diagnosis, Patient Centered, Bangil general Hospital 


\section{PENDAHULUAN}

Keperawatan medikal bedah adalah bagian dari pelayanan keperawatan profesional yang didasarkan ilmu dan teknik keperawatan medikal bedah berbentuk pelayanan bio-psiko-sosio-spiritual yang komprehensif ditujukan pada orang dewasa dengan atau yang cenderung mengalami gangguan fisiologi dengan atau tanpa gangguan struktur akibat trauma. Keperawatan medikal bedah merupakan bagian dari keperawatan, dimana keperawatan itu sendiri adalah : Bentuk pelayanan profesional yang merupakan bagian integral dari pelayanan kesehatan, berbentuk pelayanan bio-psiko-sosiospiritual yang komprehensif ditujukan pada individu, keluarga dan masyarakat baik sakit maupun sehat yang mencakup seluruh proses kehidupan manusia. Pelayanan keperawatan berupa bantuan yang diberikan dengan alasan : kelemahan fisik, mental, masalah psikososial, keterbatasan pengetahuan, dan ketidakmampuan dalam melakukan kegiatan sehari-hari secara mandiri akibat gangguan patofisiologis, (CHS, 1992).

Lingkup pelayanan keperawatan medikal bedah kepada pasien, selalu memandang pasien secara holistik/menyeluruh baik Bio-Psiko-sosialkultural-Spiritual. Dalam setiap tindakan, perawat dituntut untuk memberikan asuhan keperawatan secara professional sesuai dengan standarisasi profesi keperawatan. Pelayanan ini diberikan oleh seorang perawat yang berkompetensi dan telah menyelesaikan pendidikan profesi keperawatan pada jenjang yang lebih tinggi. Perawat dalam melaksanakan tugasnya sudah melalui jenjang Pendidikan Formal yang sudah ditetapkan oleh Pemerintah. Ilmu pengetahuan terus berubah dari waktu ke waktu (dinamis), sehingga dalam memberikan asuhan keperawatan pada Klien berdasarkan perkembangan ilmu pengetahuan terbaru Pelaksanaan asuhan keperawatan melaui tahapan dalam proses keperawatan berdasarkan pendekatan ilmiah. Perawat medikal bedah dalam melaksanakan tugasnya dituntut untuk dapat menerapkan asas etika keperawatan yang ada, meliputi asas Autonomy (menghargai hak pasien/ kebebasan pasien), Beneficience (menguntungkan bagi pasien), Veracity (kejujuran), Justice (keadilan).
Tujuan pelayanan keperawatan medikal bedah adalah untuk memberikan asuhan keperawatan bagi pasien dengan gangguan fungsi tubuh, pasien yang perlu penanganan diantara adalah preventif, promotif, dan kuratif.. Disamping itu juga pasien dengan potensial atau adanya kerusakan organ umumnya dan mengurangi kesakitan serta kematian yang masih dapat diatasi pada pasien - pasien dengan penyakit medikal bedah.

Proses perawatan merupakan suatu metode bagi perawat untuk Memberikan asuhan keperawatan kepada klien. Beberapa pengertian proses kaparawatan adalah sebagai berikut Suatu metoda pemberian asuhan keperawatan yang sistematis dan rasional (Kozier, 1991).

Metoda pemberian asuhan keperawatan yang terorganisir dan sistematis, berfokus pada respon yang unik dari individu terhadap masalah kesehatan yang aktual dan potensial (Rosalinda,1986). Suatu aktifitas yang dinamika dan berkelanjutan yang meliputi interaksi perawat klien dan proses pemecahan masalah. Proses keperawatan bukan hanya sekedar pendekatan sistematik dan terorganisir melalui enam langkah dalam mengenali masalah-masalah klien, namun merupakan suatu metode pemecahan masalah baik secara episodik maupun secara linier. Kemudian dapat dirumuskan diagnosa keparawatannya, dan cara pemecahan masalah.

Salah satu dari proses keperawatan adalah menentukan diagnosa keperawatan. Penentukan diagnosa keperawatan berdasarkan teori yang digunakan salah satunya adalah teori dari Carpenito yaitu respon pasien sebagai pedoman dalam penentuan diagnosa keperawatan. Teori tersebut sudah tidak sejalan dengan keadaan yang berkembang saat ini. Apabila pentuan diagnosa berdasarkan dari respon pasien, maka teori ini tidak bisa menjawab kebutuhan pasien karena pasien yang dirawat di rumah sakit tidak selalu bisa merespon atau mengeluh, tidak sejalan dengan tim medis. Penentuan diagnosa yang salah maka akan berdampak pada penyususnan intervensi juga akan salah.

Berdasarkan teori dari carpenito bahwa masalah keperawatan adalah respon dari pasien , dimana teori tersebut tidak menjawab masalah pasien, maka peneliti 
ingin membuat suatu pedoman dalam penentuan diagnosa yang mampu menjawab kesulitan dari perawat dalam menentukan diagnosa.

Perbedaan penentuan diagnosa
keperawatan akan menimbulkan
permasalahan yang sangat besar, diantaranya adalah tidak terselesaikannya permasalahan pasien, tidak terjadinya sinkronisasi antara pelayanan keperawatan dengan permasalahan pasien, tidak sejalannya pelayanan keperawatan dan kedokteran. Hal ini akan berdampak pada perpanjangan waktu rawat dan biaya perawatan semakin tinggi.

Permasalahan perawat dalam penentuan diagnosa keperawatan, maka peneliti membuat suatu terobosan tentang tata cara penentuan diagnosa keperawatan berdasarkan teori Faye Glenn Abdellah dengan teori patient centered. Teori ini memberikan petunjuk kepada kepada perawat bahwa penentuan masalah keperawatan adalah berdasarkan gangguan fungsi tubuh bukan pada respon pasien. Kelebihan teori ini dalam menyelesaikan permasalahan pasien Antara lain adalah sejalan dengan tim medis dan sesuai dengan keluhan yang bertolak pada gangguan fungsi tubuh.

Harapan perawat dalam menentukan diagnosa atau masalah keperawatan adalah adanya standart yang sama untuk bisa digunakan semua perawat sehingga perawat mudah untuk menentukan tindakan dan akan menyelesaikan permasalahan pasien, hal ini sesuai dengan visi misi Program Studi D III keperawatan Kampus Sidoarjo yaitu “" Menjadi Program Studi Penghasil Tenaga Keperawatan Vokasi Bertaraf Global Yang Kompeten Dan Kompetitif, Unggul, Dalam Intensive Care Berdasarkan Moral Dan Etik Tahun 2020".

\section{METODE}

Peserta pengabdian masyarakat adakah perwakilan perawat yang berdinas di ruang rawat inap. Setelah mengikuti program pengabdian, diharapkan peserta ini akan melakukan desiminasi ke perawat yang belum mengikuti pelatihan sehingga semua perawat akan terpapar tata cara dalam menentukan diagnose keperawatan

Pelaksanaan pengabdian masyarakat dilakukan di RSUD Bangil pada bulan ke
September dan Oktober tahun 2020 dengan pelaksana Tim Dosen dan mahasiswa.

Metode pelaksanaan menggunakan metode ceramah dan simulasi serta diskusi yang dikemas dalam bentuk workshop.

\section{HASIL}

Kegiatan PPM yang dilaksanakan dengan acara tatap muka dengan protocol Kesehatan karena dimasa pandemi dan praktek penentuan diagnose keperawatan. berjalan dengan baik dan lancar. Pertemuan tatap muka dengan metode ceramah dan demonstrasi, dilanjutkan latihan/praktek untuk membuat atau menentukan diagnose keperawatan, mulai dari penentuan masalah fisiologi yang tergnggu pada pasien sampai penentuan masalah diagnose keperawatan. Kegiatan ini dilaksanakan sehari yaitu bulan Oktober 2020 dengan tiga kali putaran, hal ini disebabkan suasana covid 19 dan setiap putaran diikuti oleh 20 perawata dari pukul 07.30-12.00 WIB. Peserta kegiatan berjumlah 20 orang perawat dirawat inap RSUD Sidoarjo dan lokasi penyelenggaraan pelatihan di Ruang pertemuan lantai 3 . Pelaksanan kegiatan PPM ini dilakukan oleh 3 (tiga) orang tim pengabdi dan 5 orang mahasiswa dengan pokok bahasan yang disampaikan mengenai: 1. Permasalahan dalam menentukan diagnose keperawatan, 2. Pemaparan teori patien centered dari abdella faye 3. Pengembangan dalam menentukan diagnose keperawatan 4. Simulasi atau Latihan dalam menentukan diagnose keperawatan 5. Evaluasi hasil dalam menetukan diagnose keperawatan yang telah disusun. Keterbatasan waktu pertemuan mengakibatkan tidak semua materi dapat disampaikan dengan detil. Kegiatan yang diawali dengan ceramah dan demonstrasi ini kemudian dilanjutkan latihan. Dari kegiatan latihan tampak bahwa perawat merasa waktu pertemuan sangat singkat.

\section{PEMBAHASAN}

Kegiatan program pengabdian masyakat tentang Peningkatan Kapasitas kemampuan Perawat Dalam Menentukan Diagnosa Keperawatan Berdasarkan Teori Patient Centered Di RSUD Bangil Kabupaten Pasuruan secara umum berjalan dengan lancar. Kepala bagian Pendidikan dan pelatihan dan Perawat ruang rawat inap 
beserta pegawai membantu mempersiapkan tempat dan mengkoordinir peserta program pengabdian masyarakat. Peserta program pengabdian masyarakat merupakan perawat ruang rawat inap mulai kelas 1 sampai kelas III dan ruang ICU. Tempat yang dipakai untuk kegiatan tersebut adalah salah satu pertemuan lantai 3 yang terdapat pada RSUD Bangil Kabupaten Pasuruan. Sebelum melakukan kegiatan program pengabdian masyarakat pemateri atau tim memperkenalkan diri terlebih dahulu kemudian mencoba menggali pengetahuan dasar tentang cara menentukan diagnose keperawataan. Pemateri mengajukan beberapa pertanyaan mengenai pengertian diagnose keperawatan, karakteristik diagnose keperawatan diruang rawat inap, perencanaan keperawatan. Setelah menggali pengetahuan dasar kemudian pemateri mulai memaparkan materi tentang cara penentuan diagnose keperawatan. Selama kegiatan program pengabdian masyarakat berlangsung tampak peserta antusias dan memperhatikan isi materi kegiatan. Kegiatan pemberian materi berlangsung selama kurang lebih 45 menit dan di akhir sesi pemateri memberikan kesempatan kepada peserta untuk mengajukan pertanyaan terkait materi yang telah disampaikan. Didapatkan 3 pertanyaan dari peserta penyuluhan terkait isi materi. Setelah menjawab pertanyaan dari peserta, pemateri melakukan evaluasi terkait pemberian materi yang telah disampaikan dengan cara memberikan pertanyaan dan memberikan kesempatan kepada peserta untuk menjawab pertanyaan tersebut. Peserta yang mampu menjawab pertanyaan mendapatkan door prize sebagai tanda apresiasi dan setelah itu kegiatan penyuluhan ditutup dengan kegiatan foto bersama antara pemateri dengan perawat peserta program pengabdian masyarakat. Adapun kendala yang dijumpai selama proses kegiatan adalah program ini dilaksanakan pada masa pandemic covid-19 sehingga pelaksanaan dengan peserta 20 orang perawat setiap kegiatan dan diadakan 3 kali angkatam sehingga menambah waktu dalam kegaiatan ini. Meskipun dilaksanakan dalam masa pandemic peserta tetap antusia menngikuti kegiatan dari awal sampai akhir.

\section{KESIMPULAN DAN SARAN}

a. Kesimpulan

1. Kegiatan pengabdian kepada masyarakat mengenai Peningkatan Kapasitas kemampuan Perawat Dalam Menentukan Diagnosa Keperawatan Berdasarkan Teori Patient Centered Di RSUD Bangil telah terlaksana dengan baik.

2. Kegiatan pengabdian kepada masyarakat mengenai Peningkatan Kapasitas kemampuan Perawat Dalam Menentukan Diagnosa Keperawatan Berdasarkan Teori Patient Centered Di RSUD Bangil mendapatkan respon yang antusias dari para perawat, pimpinan Rumas sakit : bidang keperawatan dan bagian Pendidikanpelaatihan.

3. Didapatkan 3 pertanyaan dari peserta program pengabdian masyarakat terkait materi penentuan diagnose keperawatan dan perawat di RS tersebut mengharapkan ada kegiatan pengabdian masyakat kembali terkait dalam keperawatan.

b. Saran

Kegiatan pengabdian seperti ini dapat dilakukan secara rutin baik di lokasi yang sama maupun di lokasi yang berbeda dengan sasaran masyarakat yang benar-benar membutuhkan pelayanan kesehatan terutama mengenai penyusunan atau penentuan diagnose keperawatan

\section{KEPUSTAKAAN}

Barnum, N. (1998). Nursing Theory, Analisis, application, evaluation. $5^{\text {th }}$ ed. New York: Lippincott.

Basavanthappa.,(2007). Nursing Theories. Mosby Company. Jaypee Brother Medical Publisher. New Delhi. India

Berman,A. et al. (2008). Fundamental of Nursing. Concepts, Process and Practice. Ed. $8^{\text {th }}$. Pearson. New Jersey. USA

Black, J M \& Hawks, J. (2001). Medical Surgical Nursing : Clinical 
Management For Positive Outcomes $7^{\text {th }}$. Philadelphia : Elsevier Saunders

Brunner \& Suddarth, (2002) Medical Surgical Nursing : Clinical Management For Positive Outcomes $7^{\text {th }}$. Philadelphia : Elsevier Saunders.

George, J.B. (1995). Nursing Theories : The Base For Profesional Nursing Practice $\left(4^{\text {th }}\right)$, USA : Appleton \& Lannge.

George B, Julia (1995). Nursing Theories the base for professional nursing
Practice Ed 4. Apleton \& lange, East Norwalk, Connecticut.

Guyton, E. (2001), Fisiologi Kedokteran, Jakarta, EGC.

Marriner Tomey, A. \& Alligood, M. R. 2006. Nursing Theorists And Their Work, 6th edition. St. Louis: Mosby.

Meleis, AI. (2006). Theoretical Nursing, Development and Progress. Ed. $3^{\text {rd }}$. Lippincott. Philadelphia 